\title{
Study of congenital malformation in tertiary care centre, Mumbai, Maharashtra, India
}

\author{
Prasannajeet Kokate*, Roshni Bang
}

\begin{abstract}
Department of Obstetrics and Gynaecology, CAMA and Albless hospital, JJ group of hospitals and GGMC, Mumbai,
\end{abstract} India

Received: 09 October 2016

Accepted: 28 November 2016

\section{*Correspondence:}

Dr. Prasannajeet Kokate,

E-mail: prasannajeetkokate@gmail.com

Copyright: (C) the author(s), publisher and licensee Medip Academy. This is an open-access article distributed under the terms of the Creative Commons Attribution Non-Commercial License, which permits unrestricted non-commercial use, distribution, and reproduction in any medium, provided the original work is properly cited.

\section{ABSTRACT}

Background: Birth defects are important cause of neonatal morbidity and mortality. Congenital anamolies are defined as structural and functional abnormalities including metabolic disorders present at birth. There are several known factors that are associated such as maternal infection like TORCH, genetic factors, drugs, maternal age, Consanguinity. Screening in late first and second trimester is important tool to reduce the prevalence.

Methods: A retrospective study was done. Data was collected and analyzed. Fetal outcome was assessed. Variables like maternal age, parity, consanguinity, abortions, sibling with malformation, nutrition, smoking, alcoholism, family history of congenital anomalies, conceived after infertility treatment, maternal diabetes, infections, fever, drugs, history of intrauterine deaths were critically evaluated.

Results: Out of total 5020 deliveries, 50 babies with congenital anomalies identified. Incidence being $0.9 \%$, commonest congenital anomalies involving craniospinal system $(44 \%)$. Second most common is musculoskeletal system (30\%). Consanguinity is single most important factor which was found to increase the risk of congenital anomalies in our study. In $40 \%$ of the cases consanguinity was noted. Most common perinatal risk factors are preterm labor $(22 \%)$, polyhydramnios $(8 \%)$ and breech (16\%). The fetal outcome was $80 \%$ of the babies were compatible with life and $20 \%$ were non compatible.

Conclusions: In the present study, most of the mothers who had anomalous fetuses had risk factors like consanguinity and previous history of abortions. Hence the need for focused screening in this high risk category. A level II targeted scan is done at 18-20 weeks and again at 24 weeks to exclude anomalies and reduce the prevalence. Once an anomaly is detected, various management options are to be discussed with the patients in consultation with neonatologist, pediatric surgeon and neurosurgeon when necessary. If parents are willing to continue the pregnancy with compatible congenital anamolies in baby then pregnancy may be continued. But if the congenital anamoly is imcompatible with life then pregnancy should be terminated. This study was conducted to study the incidence of various congenital anamolies in babies and their possible etiological factors in the population visiting to tertiary care hospital at Mumbai.

Keywords: Anamolies, Consanguinity, Targeted scan

\section{INTRODUCTION}

Birth defects are important cause of neonatal morbidity and mortality. These defects are of prenatal origin resulting from defective embryogenesis or intrinsic abnormalities in the process of development. Birth defects can be isolated abnormalities or part of a syndrome and continue to be an important cause of neonatal and infant morbidity and mortality. ${ }^{1}$ Congenital anamolies are defined as structural and functional abnormalities including metabolic disorders present at birth. There are several known factors that are associated 
such as maternal infection like TORCH, genetic factors, drugs, maternal age, and consanguinity. Screening in late first and second trimester is important tool to reduce the prevalence. Ultrasound is the best possible non-invasive technique available to detect any congenital anomalies in pregnant women which will help to identify the severity of the disease, its outcome leading to pregnancy termination or gives an opportunity for fetal therapy or better neonatal care. This study was conducted to evaluate the incidence of structural congenital anomalies and to predict the variables which contribute in the incidence of congenital anomalies so that we can reduce the related perinatal morbidity and mortality. ${ }^{2,3}$

\section{METHODS}

A retrospective study was done. Data was collected and analysed.

Fetal outcome was assessed. Variables like maternal age, parity, consanguinity, abortions, sibling with malformation, nutrition, smoking ,alcoholism, family history of congenital anomalies, conceived after infertility treatment, maternal diabetes, infections, fever, drugs, history of intrauterine deaths were critically evaluated.

\section{RESULTS}

Table 1: Age.

\begin{tabular}{|lll|}
\hline Age & Number & Percentage \\
\hline$<20$ & - & 0 \\
\hline $20-30$ & 38 & 76 \\
\hline$>30$ & 12 & 24 \\
\hline
\end{tabular}

Table 2: Parity.

\begin{tabular}{|lll|}
\hline Parity & Number & Percentage \\
\hline Primigravida & 18 & 36 \\
\hline $2^{\text {nd }}$ Gravida & 17 & 34 \\
\hline $3^{\text {rd }}$ Gravida & 12 & 24 \\
\hline $4^{\text {th }}$ or More & 03 & 6 \\
\hline
\end{tabular}

Table 3: Gestational age.

\begin{tabular}{|lll|}
\hline Gestational age & Number & Percentage \\
\hline$<28$ wks & 10 & 20 \\
\hline $28-37$ wks & 13 & 26 \\
\hline$>37$ wks & 24 & 48 \\
\hline After birth & 03 & 06 \\
\hline
\end{tabular}

Out of total 5020 deliveries, 50 babies with congenital anomalies identified. Incidence being $0.9 \%$, commonest congenital anomalies involving craniospinal system (44\%) (Table 8). Second most common is musculoskeletal system (30\%) (Table 8$) .88 \%$ of cases were registered at our hospital. $76 \%$ cases were in the age group of 20- 30 yrs and $24 \%$ were in the age group of
$>30$ yrs (Table 1). $36 \%$ cases were primigravidae (Table 2 ). In $10 \%$ of cases history of abortions was present (Table 5). About $20 \%$ congenital anomalies were detected before 28 wks (Table 3). $26 \%$ of the cases were diagnosed between 28-37 wks; most of them have no previous antenatal scans due to infrequent antenatal visits (Table 3). Most common perinatal risk factors are preterm labor $(22 \%)$, polyhydramnios $(8 \%)$ and breech (16\%) (Table 6). Congenital malformations contribute to $20 \%$ of perinatal mortality. Even though congenital anomalies of minor degree, prematurity along with associated maternal contributing factors are responsible for the perinatal mortality.

Table 4: Blood group.

\begin{tabular}{|lll|}
\hline Blood group & Number & Percentage \\
\hline O Positive & 14 & 28 \\
\hline A Positive & 14 & 28 \\
\hline B Positive & 14 & 28 \\
\hline AB Positive & 05 & 10 \\
\hline A Negative & 03 & 6 \\
\hline
\end{tabular}

Table 5: Risk factors.

\begin{tabular}{|lll|}
\hline Risk factor & Number & Percentage \\
\hline Consanguinity & 20 & 40 \\
\hline Abortions & 5 & 10 \\
\hline $\begin{array}{l}\text { History of } \\
\text { intrauterine fetal } \\
\text { death }\end{array}$ & 4 & 8 \\
\hline Maternal diabetes & 3 & 6 \\
\hline Age > 30 yrs & 12 & 24 \\
\hline Infections, fever & 4 & 8 \\
\hline $\begin{array}{l}\text { Sibling with } \\
\text { malformation }\end{array}$ & 2 & 4 \\
\hline
\end{tabular}

Table 6: Associated risk factors.

\begin{tabular}{|lll|}
\hline Risk factor & Number & Percentage \\
\hline Preterm & 11 & 22 \\
\hline Polyhydromnios & 4 & 8 \\
\hline Breech & 8 & 16 \\
\hline IUGR & 3 & 6 \\
\hline Oligohydramnios & 2 & 4 \\
\hline Risk factor & Number & Percentage \\
\hline
\end{tabular}

\section{DISCUSSION}

We found the incidence of congenital anomalies in our hospital was $0.9 \%$ in our study which is equal to the general incidence in developing countries. ${ }^{2-5}$

In our study $44 \%$ (Table 8 ) of cases involved craniospinal system. Meningomylocele amounting to $12 \%$ cases of NTDs and most common factor contributing to perinatal mortality. 
Table 7A: Distribution of anomalies: Craniospinal $22(44 \%)$.

\begin{tabular}{|lll|}
\hline Hydrocephalous & 5 & $\mathbf{1 0}$ \\
\hline Meninomylocele & 6 & 12 \\
\hline Encephalocele & 1 & 2 \\
\hline Spina bifida & 1 & 2 \\
\hline Holoprosencephaly & 1 & 2 \\
\hline Dolicocephaly & 1 & 2 \\
\hline Acrania & 1 & 2 \\
\hline Anencephaly & 5 & 10 \\
\hline Lisinocephaly & 1 & 2 \\
\hline
\end{tabular}

Table 7A: Distribution of anomalies: Craniospinal $22(44 \%)$.

\begin{tabular}{|lll|}
\hline Hydrocephalous & 5 & $\mathbf{1 0}$ \\
\hline Meninomylocele & 6 & 12 \\
\hline Encephalocele & 1 & 2 \\
\hline Spina bifida & 1 & 2 \\
\hline Holoprosencephaly & 1 & 2 \\
\hline Dolicocephaly & 1 & 2 \\
\hline Acrania & 1 & 2 \\
\hline Anencephaly & 5 & 10 \\
\hline Lisinocephaly & 1 & 2 \\
\hline
\end{tabular}

Table 7B: Distribution of anomalies: Abdominal wall defects $-2(4 \%)$.

\begin{tabular}{|lll|}
\hline Imperforated anus & 1 & 2 \\
\hline Gastroschisis & 1 & 2 \\
\hline
\end{tabular}

Table 7C: Distribution of anomalies: Cardiovascular $-3(6 \%)$.

\begin{tabular}{|lll|}
\hline VSD & 1 & 2 \\
\hline PDA & 1 & 2 \\
\hline Complex cardiac anamoly & 1 & 2 \\
\hline
\end{tabular}

Table 7D: Distribution of anomalies: Renal - 2 (4\%).

\begin{tabular}{|lll|}
\hline Bilateral hydronephrosis & 1 & 2 \\
\hline Renal agenesis & 1 & 2 \\
\hline
\end{tabular}

Table 7E: Distribution of anomalies: Musculoskeletal$15(30 \%)$.

\begin{tabular}{|lll|}
\hline Cleft lip & 1 & 2 \\
\hline Cleft Palate & 3 & 6 \\
\hline Cleft lip and Palate & 7 & 14 \\
\hline Limb defects & 3 & 6 \\
\hline Polydactyly & 1 & 2 \\
\hline
\end{tabular}

Second most common congenital anomalies involved facial and neck structures but most of them are non-fatal but contributing to perinatal morbidity (Table 8). the increase in perinatal mortality was mainly due to associated preterm labor, prematurity, polyhydramnios, maternal diabetes and IUGR (Table 6).

Table 8: Gross distribution of anamolies.

\begin{tabular}{|lll|}
\hline Craniospinal & 22 & 44 \\
\hline Cardiovascular & 2 & 4 \\
\hline Renal & 3 & 6 \\
\hline Abdominal & 2 & 4 \\
\hline Musculoskeletal & 15 & 30 \\
\hline Multiple congenital anamolies & 6 & 12 \\
\hline
\end{tabular}

Table 9: Fetal outcome.

\begin{tabular}{|lcl|}
\hline Abortions & 1 & 2 \\
\hline Preterm vaginal delivery & 11 & 22 \\
\hline Term vaginal delivery & 14 & 28 \\
\hline LSCS & 15 & 30 \\
\hline MTP & 09 & 18 \\
\hline
\end{tabular}

Consanguinity is single most important factor which was found to increase the risk of congenital anomalies in our study. $^{22}$ In $40 \%$ of the cases consanguinity was noted (Table 5).

Maternal Age $>30$ is also the most important risk factor found to increase the risk of congenital anamoly in our study.

The fetal outcome was $80 \%$ of the babies were compatible with life and $20 \%$ were non compatible.

Social awareness about the consanguinity and if unavoidable, genetic counselling are important measures that can be done to reduce the consanguinity.

Preconceptional counselling and Supplementation of folic acid can be done to reduce the incidence of NTD.

\section{CONCLUSION}

In the present study, most of the mothers who had anomalous fetuses had risk factors like consanguinity and previous history of abortions. Hence the need for focused screening in this high risk category. Pre scan counselling with karyotyping, triple screen and relevant serology has to be done.

A level II targeted scan is done at 18-20 weeks and again at 24 weeks to exclude anomalies. A single ultrasound examination is allowed per pregnancy, the mid trimester scan at 18- 20 weeks clearly represents the best time to accomplish the most. Once an anomaly is detected, various management options are to be discussed with the patients in consultation with neonatologist, pediatric surgeon and neurosurgeon when necessary.

Though most of the anomalies are compatible with life, 
If parents are willing to continue the pregnancy with compatible congenital anamolies in baby then pregnancy may be continued. But if the congenital anamoly is imcompatible with life then pregnancy should be terminated. This study was conducted to study the incidence of various congenital anamolies in babies and their possible etiological factors in the population visiting to tertiary care hospital at Mumbai.

\section{Funding: No funding sources}

Conflict of interest: None declared

Ethical approval: The study was approved by the Institutional Ethics Committee

\section{REFERENCES}

1. Rosano A. Infant mortality and congenital anomalies from 1950 to 1994: an international perspective. Journal of epidemiology and community health. 2000;54:660-6.

2. Kalter H. Congenital malformations: etiologic factors and their role in prevention (first of two parts). The New England journal of medicine. 1983;308:424-31.

3. Biri A. Birth prevalence and distribution of congenital anomalies in a university hospital. Perinatol Dergisi. 2005; 13:86-90.

4. Bittar Z. Major congenital malformations presenting in the first 24 hours of life in 3865 consecutive births in south of Beirut. Incidence and pattern. The Lebanese medical Journal. 1998;46:256-60.

5. Wen SW. Patterns of infant mortality caused by major congenital anomalies. Teratology. 2000;61:342-6.

6. Rajangam S. Consanguinity and chromosomal abnormality in mental retardation and or multiple congenital anomaly. Journal of the Anatomical Society of India. 2007;56:30-3.

7. Mir NA, Galczek WC, Soni A. Easily identifiable congenital malformations in children: Survey of incidence and pattern in 32,332 live born neonates. Ann Saudi Med. 1992;12(4):366-71.

8. Sawardekar KP. Profile of major congenital malformations at Nizwa Hospital, Oman: 10-year review. Journal of paediatrics and child health. 2005;41:323-30.

9. Verma M. Congenital malformations - a retrospective study of 10,000 cases. Indian Journal of pediatrics. 1991;58:245-52.

10. Shafei A. Congenital malformations and consanguinity. The Australian and New Zealand Journal of Obstetrics and Gynaecology. 1986;26:168-72.

11. Tayebi N. The prevalence of congenital malformations and its correlation with consanguineous marriages. Oman Medical Journal 2010;25:37-40.

12. List of some birth defects related studies conducted in India.Study location No. Of Malformed Babies Risk Factors Most Predominant Anomalies,
Congenitalmal formations at birth in Central India: A rural medical college hospital based data. Maharashtra January 2005 and 31July 2007.

13. A community-based survey 14 of visible congenital anomalies in rural Tamil Nadu. Rural Areas of Tamil Nadu. 2004-2005.

14. Birth defects surveillance study. Genetic Research Centre, National Institute for Research in Reproductive Health, Mumbai, India. 1994.

15. Chromosomal abnormalities: genetic disease burden in India. Guru Nanak Dev University, Amritsar, India. March 1991 - March 2005.

16. Congenital Malformations at Birth -A Prospective Study from South India. (Department of Pediatrics, Jawaharlal of Post- Graduate Medical Education and Research, Pondicherry. September 1989 to December 1992.

17. Pattern of distribution of congenital anomalies in stillborn18: a hospital based prospective study. Gandhi Medical College, Hyderabad. July 2007 to December 2009.

18. The incidence of major congenital malformations in Mysore. 1967 through 1969.

19. Congenital Malformations at Birth (Department of Obstetrics and Gynecology, Banaras Hindu University, Varanasi. 1988 to December 1989.

20. Taksande A, Vilhekar K, Chaturvedi P, Jain M. Congenital malformations at birth in Central India: A rural medical college hospital based data. Indian J Hum Genetics. 2010;16:159-63.

21. Bhat BV, Ravikumara M. Perinatal mortality in India-Need for introspection. Indian J Matern Child Health. 1996;7:31-3.

22. Agarwal SS, Singh U, Singh PS, Singh SS, Das V, Sharma A, et al. Prevalence and spectrum of congenital malformations in a prospective study at a teaching hospital. Indian J Med Res. 1991;94:413-9.

23. Taksande A, Vilhekar K, Chaturvedi P. Congenital malformations at birth in Central India: A rural medical college hospital based data. Indian J Hum Genet. 2010;3:159-63.

24. Mathur BC, Karan S, Vijaya Devi KK. Congenital malformations in the newborn. Indian Pediatr. 1975 Feb;12:179-83.

25. Mohanty C, Mishra OP, Das BK, Bhatia BD, Singh G. Congenital malformation in newborn: A study of 10,874 consecutive births. J Anat Soc India. 1989;38:101-11.

26. Suguna Bai NS, Mascarene M. An etiological study of congenital malformation in the newborn. Indian Pediatr. 1982;19:1003-7.

27. Dutta V, Chaturvedi P. Congenital malformations in rural Maharashtra. Indian Pediatr. 2000;37:998-1001.

28. New Delhi: Reproductive health; Annual report 2002-03. Indian Council of Medical Research; p. 91

29. Sridhar K. A community-based survey of visible congenital anomalies in rural Tamil Nadu. Indian J Plast Surg. 2009;42:S184-91. 
30. Patel ZM, Adhia RA. Birth defects surveillance study. Indian J Pedlatr. 2005;72:489-49.

31. Bhat V, Babu L. Congenital Malformations at Birth A Prospective Study from South India. India J Pediatr. 1998;65:873-81.

32. Ramakrishna D. Pattern of distribution of congenital anomalies in stillborn: a hospital based prospective study. IJPBS. 2011;2:604-10.
Cite this article as: Kokate P, Bang R. Study of congenital malformation in tertiary care centre, Mumbai, Maharashtra, India. Int J Reprod Contracept Obstet Gynecol 2017;6:89-93. 